\title{
Teachers Tell Us about Full Inclusion
}

\author{
Thaís Campos Teixeira1, Juan José Mouriño Mosquera², Claus Dieter Stobäus ${ }^{3}$ \\ ${ }^{1}$ Secretaria Municipal de Educação, Porto Alegre-RS, Brazil \\ ${ }^{2}$ Postgraduate Programs in Education, Pontifical Chatolic University of Rio Grande do Sul, Porto Alegre-RS, \\ Brazil \\ ${ }^{3}$ Postgraduate Program in Education and in Biomedical Gerontology, Pontifical Chatolic University of Rio \\ Grande do Sul, Porto Alegre-RS, Brazil \\ Email: stobaus@pucrs.br
}

Received 5 February 2015; accepted 19 June 2015; published 25 June 2015

Copyright (C) 2015 by authors and Scientific Research Publishing Inc.

This work is licensed under the Creative Commons Attribution International License (CC BY). http://creativecommons.org/licenses/by/4.0/

(c) $\underset{\mathrm{EY}}{\mathrm{i}}$ Open Access

\begin{abstract}
It is a qualitative research, interviewing 11 teachers reponses of Speical Education PUCRS about over who they think and they say and they act, with the base literature on authors of Special Education and Inclusive Education. We conducted a content analysis of the responses, similar to those of previous studies categories: Use of terminologia-use the nomenclature as synonyms or different; Teacher training come from different areas, with interests and later links with the Special Education, with little training in the area; Satisfactions-happy when their students' progress more in daily life activities, supported by family/colleagues; Dissatisfactions-dislike when parents do not act complementing tasks; Difficulties and trouble-devalued as teachers, face problems in school and beyond, difficulty performing continuous and in-service education for lack of support of the family; Teaching and constant updates are necessary, especially about continuing evaluation, requiring monitoring with multi/interdisciplinary team, the necessity on observe minimal behavioral and cognitive changes are highlighted in the reports; Learning should improve the quality of life of students, progress with language, behavioral controls, increase in social interaction. We highlight the need to discuss about the theories used, the need to perform multi/interdisciplinary activities, have support to continuing education and contextualized curriculum changes and reforms.
\end{abstract}

\section{Keywords}

Full Inclusion, Inclusive Education, Inclusion, Teacher's Education

\section{Introduction}

When we began this research report, it is worth noting that the initial data are analyzed from interviews con- 
ducted in 2000, now serving for this renewed discussion and recontextualization, since it seems to us that many of the results coincide with that data and the literature, but not all to discuss between us, as authors, we just refer the reader to the initial data and projections, and then delve into the arguments that has been done and what still needs to be modified.

For our research, we think that knowing what these teachers thought and said about how they act can help us in understanding a possible better Full Inclusion, more inclusive education and Education for All, more flexible, productive, especially within/toward the social justice.

\section{Some Theoretical Considerations}

Palacios, Marchesi, \& Coll (1990: p. 23) point out that:

The willingness of teachers to integrate students with learning problems, especially if these problems are serious and have a permanent character, is a determinant factor greatly the results that obtains. Therefore, a positive attitude is already an important first step that facilitates the education of these students in an inclusive school.

This thought brings us to the reality that it's the teachers who have a key role in acting with the students' Carrier Special Educational Needs (in Portuguese PNEE, Brasil, 1994, 1996), at that time, also as Persons with Disabilities (2012) or mindfulness in English.

There was a long historical path in which the exclusion, prejudice and rejection were constant and gifts, until we get what we want and we propose today.

Historically mankind has gone through stages that can be summarized. According to Correia (1997), exclusion occurred when different people were hidden or even sentenced to death, especially if we recalled the Greek and Roman times, and even the Middle Ages.

The segregation, from the late 19th century and the early 20th, in which he created the so-called special schools where the policy was to separate and isolate children from the main group and majority of society, trying to show a commitment to problem solving, recalling the famous and discriminating tests, including IQ.

After two World Wars, a humanist revival in the 60s and the great civil and social movements, called Transition, appeared in 1972, the famous legal challenge in the United States, in that the Association of Retarded Children of Pennsylvania placed in staff the opportunity to educate all children, who recieve from that moment the right to be integrated into the school as other students (American Association on Mental Retardation, 1997).

Already commented that the educational environment should be the least restrictive possible, it should provide evidence to the regular education teachers acted with all students in the class, that would favor the promotion of acceptable social relationships between students with special educational needs and those who do not possess.

The term integration which appeared in the 80s was much used in the sense of placement with the normal PNEE said for academic and social purposes in the least restrictive means possible.

Sassaki (1997: p. 41) defines social inclusion as:

The process by which society adapts to be able to include in their general social systems, people with special needs and, simultaneously, they prepare to take on their roles in the society. Social inclusion, then, is a bilateral process in which people still excluded, and seek the society, in partnership, equating problems, decide on solutions and effect and equal opportunity for all.

Integration and inclusion are used also as synonymous or very closely by some authors and organizations such as the UN, UNESCO (1994a, b) and WHO.

However, already exists in the official documentation, a strong tendency to use inclusion as a form of human and philosophical paradigm upheld.

Sassaki (1997) seems to have taken very well aware of the comprehensive inclusive ideas of a society for all, syntherized in these principles:

- Celebration of differences;

- Right to belong;

- Appreciation of human diversity;

- Humanitarian solidarity;

- Equal importance of minorities; and

- Citizens' quality of life

According to Palacios, Marchesi, \& Coll (1990), the most difficult faced problem by teachers can be expressed in how they do their practice of education with students with Special Educational Needs. 
- How to organize the classroom;

- To provide its development;

- How to provide appropriate aspects for learning;

- How to effectively handle diverse and unexpected requests;

- How to update itself; and

- How to meet the demands of family and community.

One of the relevant facts of the last decade was the Salamanca Statement, UNESCO (1994b), adopted by the World Conference on Special Needs Education: Access and Quality, held in Salamanca, Spain, between 7 and June 10, 1994.

From that meeting, UNESCO registered the concept of inclusion in the field of common education, stating the terminology inclusive class, inclusive education, inclusive education policies, inclusion in education and employment, among others.

Correia (1997: p. 66) highlights the fact that, since 1970, Deno, in his paper about Special Education as capital development, underlined in his Cascade System of Educational Services, whose goal was the placement of the child in the least restrictive means possible, and divides his system in seven levels, ranging from a less restrictive means to receipt of care in specialized institutions, in the form of an inverted pyramid, and that "the cascade of Deno is based, therefore, a concept of positive evaluation, designed to identify strong areas of educational potential, avoiding negative classification categories". This last phase is the inclusion.

Number of students

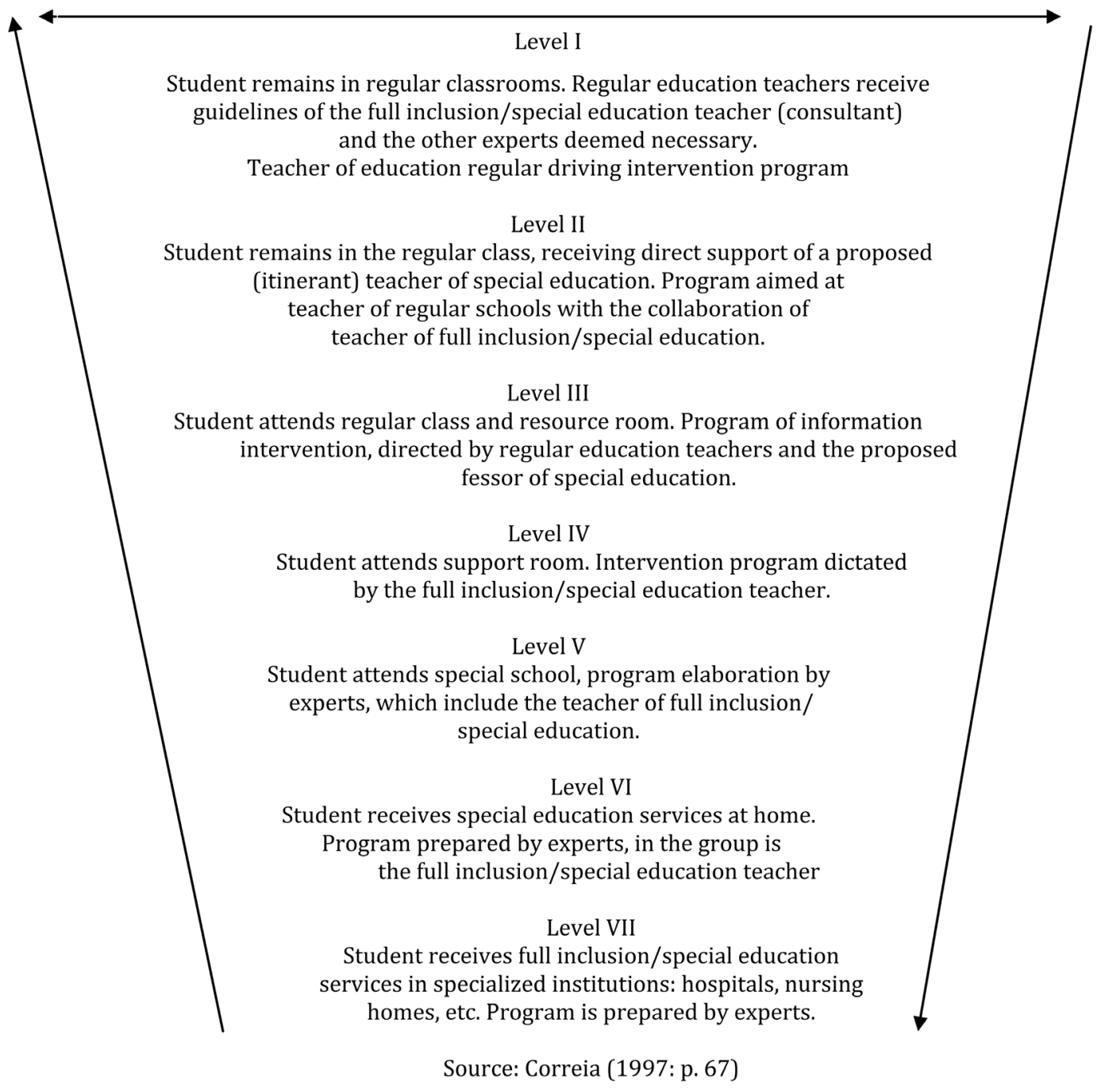


The idea of the cascade presented above, that there is a beginning of support with the support of the regular teacher for the most cases of full inclusion students in his/her regular classroom (level I), then by supported by the itinerant full inclusion teacher and the regular teacher (level II); and from level III to the last there is requested the collaboration of higher experts, and at the level VII there is necessary the institucionalization, only in some rare cases.

The finding of this problem and the dilemma of Inclusive Education foregrounds the need and priority in teacher training, which should focus on how to work in class and which therefore includes learning of all those skills and strategies to plan conveniently work in class:

- General and specific schedules;

- Curricular adaptations;

- Method (s);

- Organization of time and space and in class;

- Assessment processes;

- Techniques for diverse work; and

- Different intervention strategies on the basis of learning problems.

Finally, the confidence and the motivation of the teacher in his task is a fundamental variable that fosters positive attitudes and manifestations, when face with the integration and inclusion, leading to repercussions in the whole educational process of their students.

\section{Methodology}

The aim of our research was to analyze qualitative testimonies of academics working in the field of Special Education, with the Thematic Area with Teaching Students with Special Educational Needs and Research Questions: What do they think and act as teachers in integration/inclusion of Students with Special Educational Needs?; What satisfactions and problems reported as more frequent in their activities in the classroom?; What educational problems are most often narrated by teachers?; What learning problems are more often recounted by teachers?

Intentionally interviewed eleven professors of the School and Education-PUCRS, in Porto Alegre, who worked directly on the degree of Education-Special Education Qualification (now discontinued and replaced by the pedagogy course), with semi-structured interview, the answers to which were subjected to the technique of content analysis of Bardin (2014).

The investigation was approved at PUCRS Ethics Committee.

\section{Results}

We found the same categories of our previous work, started from Postdoctoral studies in 2000, with the data identical to the literature.

\subsection{Use of the Terminology}

Use of the classification: various authors discuss the use of terminology, in terms that are used as synonyms, as reporting "inclusion and integration would be the acceptance and welcoming to all, regardless of need or not", "integration is most widely used in Europe, inclusion is more in Canada, here would be the same".

This subcategory included the testimonies of those teachers who commented that the use of the terms Inclusion and Integration, indiscriminately, does not seem to be causing inconveniences, almost whatever use one version or another, identically equal.

The carrier term does not seem to be used as most of us, some time has been replaced worst integration lately for inclusion, also per student or person with special educational need.

Also highlight the idea that the inclusion is larger, comprehensive integration. It was noted that teachers had a concern in trying to correctly use the nomenclature, since temporally integration came before, referring to place the student in, while inclusion was necessarily greater, prepared to include society. Remembering the concept of WHO, that disability or minusvalia refers to very most important and permanent needs. The sense used by English authors, as challenge, opposition, objection, difference, is current.

The other subcategory, either as different, so as "integration is the process to get to the inclusion", or "to 
speak in deficit I report what is missing, what I do need to allow for some more".

This subcategory included the testimonies of those who considered and teachers use the terms as different, even as opposites (antonyms), especially when reporting on patients rather than students or people as well as integration rather than inclusion. Appeared several times in comments, sometimes even opposite, in the sense that integration would be greater/larger than inclusion, which would include even part of the integration, when it is just the opposite. Remember that our Brasilian legislation itself clearly speaks about carrier.

Even though we stay in our country, the least restricted to the field, often forgetting the field more, so-called prodigy or so gifted ones, who also have their constraints or difficulties, not always end up being worked on training in students Special Education. Go unnoticed in Undergraduate generally end up being forgotten.

Recalling the comments of Marchesi, Coll, \& Palacios (1999), while the attendance of 2\% or $18 \%$ - 20\%, i.e., $2 \%$ would be taken care of those students we spoke with really serious problems, necessitating have very specific care, but would be $18 \%$ - $20 \%$ of total students if we speak of those who need support to remedy their difficulties.

Recently we have again heard again speaking in changes in the proposed new use of terminology, nomenclature, now using students or persons in place of students, more in the sense that not only would those students in years of schooling or who had access to the school named but all those people who need support, anywhere, within and outside the school. Also regarding the educational term no discussion, education would be broader and may also serve other sectors of society. Already a particular denomination could be replaced by specific, those needs that each person has at some point, could be met in a specific way, not necessarily special.

From here forward, there will be more discussion and polemization. Recently we heard arguments in order to correct (the most politically correct, as some people would say in the area), for person with special educational needs, demonstrating the idea that education would be more toward the school (in the formal sense) and special that would give equal size specific, with the issue of specifically identified person. We know that these adjustments will occur (or not) next years.

It should also draw attention that can change the nomenclature to use it, but that does not mean we are all privy to the changes, its subtlety and depth. It may even be those who continue mixing the nomenclature, without knowing what you're talking about, which undoubtedly cause problems for those who know of the changes and try to be correct and current on their use.

\subsection{Teacher Training}

Many respondents come from different areas but with interests and links with later special education, few have done their training directly in Special Education, reported that "regardless of being prepared, I had to teach students with special", "did Magisterium Course then I thought about doing Physical Education, worked with cerebral palsy, no course, no nothing, I travel around the SEC, then I did Psychology", "had a friend Down in childhood, we always joked he died, so I went to work in APAE as a volunteer".

We note that sometimes the unpreparedness leads us to study more deeply and as well as note clearly how our own life story can assist in personal and professional choices that we perform later, often for life.

In this category we highlight those comments that say about the training aspects that the teacher realized, that relate either directly or indirectly, with the Special Education, ranging from a training area directly in specific course, even those who performed in several distinct areas, to choose the Special Education. Often there is a specific preparation at the undergraduate level in the area, but that does not quite complete the requirements, especially in the area of Special Education. On the one hand, specific courses and continuous, constant updates are needed, as well as continued practice, always be possible also in contact with the student, the person with SEN, knowing the context.

We are all marked by our own personal journey in our life choices, the experiences that we experience, as well as aspects of a person that we consider relevant, a mentor, a mentor, someone to guide us (guided).

We could recommend, as an aid to teachers who are in action, especially s younger, there was more support among them, as in a shared work, or even groups of special support, multi/interdisciplinary way. Not necessarily experts who know everything, but people with whom teachers could share the difficulties of everyday school life and seek possible solutions, contextualized, realistic.

We highlight Support Groups institutional character (the center itself, within it); based on equality (without hierarchy without distinction); with collaborative strategies in group work (not only more complex and inter- 
sistêmicas techniques); self-help (personal reflection and willingness and readiness to change); and in practice guidelines; immediate support in terms of time and space; support for the role of teacher with several students; technical flexibility (no ready formulas, but continuous adjustments) introductions gradual changes and remembering that everything starts from the bottom up, with the teacher, rescuing the collective of teachers and what they already do.

\subsection{Satisfactions}

They say they are very happy when their students' progress better performing activities of daily living, to be supported by their families, colleagues, society in which they are saying "we did early intervention in several cases, all went to regular school", "to see the integrated teacher with them, learning from them", "to see a person with Down Syndrome giving computer class", "a former student of ours, filed a Down student".

This category collect the testimonials on those elements that we believe that are reflecting positive comments about the work performed, including statements related to the student, the teacher, the parents, the school and other people who work in school and/or are part of the so called education system.

Also we note that is is necessary a great motivation when working with these kids (Huertas, 1997, 1998).

We highlight the fact that one of them have recognized the work done by himself with his teachers made him want to try to help her now a student who had specific problems, which is very satisfactory for the teacher and his school, demanding it precisely the experts and the school where he studied.

Report satisfaction when his students progress, no matter if it was so little, and can perform termed daily, diverse life activities or repetitive tasks necessarily with the support of parents, own colleagues and the school administration, the school where they are integrating/including student and undoubtedly the society as a whole.

\subsection{Dissatisfactions}

Appear when commenting sometimes they observed as "non-acceptance by the other students", or "do not want to invest in people as normal or different", "one student told me-the teacher left me", "limits on school that are not the same at home".

We emphasize that we must deepen the recognition of context elements that help us understand what and how we propose limits.

Highlight those less positive aspects (and some negative) commented. The issue of pre-concept up towards the consolidated presoncepts, i.e., has a predisposition to judge almost always directed so often adversely appears. This should be discussed openly with all who work in the area, from the parents to the school as a whole, the teacher in particular, to better cope with the issue

The big question here would also be limits to be discussed with all stakeholders in the area to better clarify them and consolidate opinions about the right/wrong, yes/no. What we propose or how we should act in school, as it should or could be better at home, when the teacher is not?

Teachers also report dissatisfaction when their students do not progress, cannot perform termed daily, or repetitive diverse life activities, tasks to not treat or do not show/accept limits.

\subsection{Difficulties and Problems}

Highlighted in comments as "we need a greater appreciation of education in general"," it hurts when they interrupt treatment, hampering their progress", "when there is difficulty in communication and relationship", "come straight to school without support", "is there an intern in school, drop out right into it", "the family that has no minimum training and hurts all the time, even unintentionally."

A further issue is how difficult it is to the teacher, when they have little time and poor resources to perform their tasks, and how family (and society) continue the accomplished.

The underutilization and not believe in the potential of each, both personal and family and even school and society, appears clearly placed placed as if someone spend a lot of time in improving the material conditions, even in teacher training, and this results that cannot (or even wants) to use this knowledge and materials..

Also refer to the lack of adherence to treatment (by the child, their family or lack of community support) in which it must take into account aspects such as knowledge/ignorance, preconceptions/prejudices arguably even intentional interruption of treatment or contact with experts. 


\subsection{Teaching}

Emphasize that constant updates are needed, and care during the evaluation process and the teaching on it, avoid the lack of monitoring with multi and interdisciplinary team, taking care to detect minimal behavioral and cognitive changes, as reporting "parents also signs should learn to communicate better with them", "be the teacher with the interdisciplinary team, (...), stage would be a good learning space", "understand the flexibility, limits and codes, the process as a all that is changing according to the time and context".

Emphasize on teaching in a more positive direction (and also more negative), remembering that constant updates, care and teaching during the evaluation process, avoid lack of monitoring with multi and interdisciplinary team, tending to detect minimal changes are needed behavioral and cognitive, that there should be greater focus on learning to teach.

Here appears also placed the notion of the teacher, the burnout, which affects the stress, highlighted by $\mathrm{E}$ Stobäus \& Mosquera (2001). Here we highlight the load of the piano all the time while others are playing or listening to music.

Also comment on the need for a sense of Continuing Education, ie, constant updates and aid, including some institutions and evaluation mechanisms are scored for faculty, better and continued monitoring of its students with a multidisciplinary and multi-professional team evaluation process.

We emphasize that talked about attitudes of respect for diversity, personal care the pace, and careful attention to detect minimal behavioral and cognitive changes, to visualize and develop potential. Draws attention to one of the interviewees who learn to teach better when it is accompanied, stimulated and motivated.

Stainback, \& Stainback (1999, apud Stobäus \& Mosquera, 2010) highlight the need in Inclusive Education, to recognize the strength, the incidence of what is called the hidden curriculum, giving way to an explanation of a common curriculum, in agreement with the offerings of demands, both of view of the student, as toward society, from the family and the school. For both, there are other essential elements, but highlight the need for collaboration between all effective integration between teachers and participants support team and other professionals, discuss and put into practice the decisions about changes in the curriculum, and to evaluate constantly and accurately individual development of students. Emphasize that the curriculum should leave school, toward society, which also must go and prepare welcoming.

Stobäus (2010a, b, c) and Stobäus \& Teixeira (2001a, 2001b) reminds us that evaluation can be guided by elements: assessing and placing students as classroom goals; selecting objectives and content to work; determine the types of aid (specific evaluation); evaluate and carry out follow-up during the process (formative evaluation); and value changes in skills (summative evaluation). Still remember the criteria of teaching and learning that already is enhanced in our book Education for Health (Mosquera \& Stobäus, 1984), with the contributions we make Ausubel.

\subsection{Learning}

Should lead to improvements in quality of life for students and their families, demonstrating progress in language, behavioral controls, enabling an increase in social interaction, as when they say "teachers and parents understand and follow the rhythms of the student", "day by day the child is changing, it takes much longer but get there", "us is that we will learn a lot from them, is taught by noting how they manage to do what we ask".

Respondents consider it necessary to remind everyone, students, teachers and other professionals who work in team learn differently, which should always be rescued and lead to improved quality of life for all, to occur in language progress in behavioral controls, and even an increase in social interaction. The debate about the extent to which we can or should be paternalistic, over-protective or overprotective, good guys, among other points to consider, not yet expired, is to be unveiled and deepened.

We must remind the behaviors that favor learning positively. It is important, no doubt, involve parents, highlighting as a frank, honest and realistic relationship with them is necessary, including specific programs for certain subjects; how to approach them with your children how to repeat them and reward them; difficulties and possible solutions, often simpler; time and space that parents can take in terms of learning and mediations; and ethical and moral care that underlie the intrusions.

Stobäus, \& Mosquera (2013) describe the effective participation of parents in caring for their children, both in early stimulation and no doubt with special educational needs, should take into account the reality and context of this family, evaluate and reward each evolution, simpler it is, the value that each individual makes in the sense of strengths, respecting personal rhythms and family, admitting that foreign aid is an angle of the prism of reali- 
ty, contemplating plans and goals for the future, working with (and not against) the person and the family, whether in language, in movement, in socialization, in their times and their spaces as student and family member.

\section{Conclusions}

We believe that there is a need to work better concepts and conceptions that teachers demonstrate in order to promote practices consistent with theories that use. Basic continued training must be for better quality, also specific monitoring and monitored training. We should use aid and support should be available all the time, in working with multidisciplinary and interdisciplinary teams, with professionals in areas such as Education, Psychology and Health. There are difficulties: times and rhythms are not the same at school, at home with parents and do not violate society's satisfactions: the small changes in the school, at home, extensively to a more prepared society, we should still take care in teaching rhythms and individual difficulties in learning to remember that slight changes are important.

The education of teachers should take into account continuity and updating, taking into account new paradigmatic concepts and lines of research on Inclusive Education, deepening in multidiversidade studies, especially with regard to the differences, and the approach with professionals from other fields.

In reaching this moment, we can only emphasize once again that the work could serve as a recommendation and proposal, an encouragement for further studies and reflections, especially with regard to the differences that are biological, educational, cultural or racial, among others that can be detected and that we need to deal with. Finally, the real approach and incorporation of professionals from various fields to discuss more about topics such as Education for All, Health Education, Full Inclusion/Inclusive Education, Social Education, Cultural Education.

\section{References}

American Association on Mental Retardation (1997). Retraso Mental. Definición, clasificación y sistemas de apoyo. Madrid: Alianza.

Bardin, L. (2014). Análise de Conteúdo (4th ed.) rev. atua. Lisboa: Edições 70. [original (2013). L'analyse de contenu. Paris, PUF].

Brasil (1994). Princípios básicos da Educação Especial. Brasília: MEC/CENESP.

Brasil (1996). Lei de Diretrizes e Bases da Educação Brasileira. Brasília: MEC.

Correia, L. de M. (1997). Alunos com necessidades especiais nas escolas regulares. Porto: Porto Editora.

Huertas, J. A. (1997). Motivación. Querer aprender. Buenos Aires: Aiqué.

Huertas, J. A. (1998). Estrategias de enseñanza del profesor y adquisición de aprendizajes en alumnos sordociegos. Proyecto de Investigación. Madrid: Facultad de Psicología de la Universidad Autónoma de Madrid.

Marchesi, Á., Coll, C., \& Palacios, J. (comp.). (1999). Desarrollo psicológico y educación-I. Psicología Evolutiva (2rd ed.). Madrid: Alianza.

Mosquera, J. J. M., \& Stobäus, C. D. (1984). Educação para a Saúde. Desafio para sociedades em mudança (2rd ed.). Porto Alegre: D. C. Luzzatto.

Sassaki, R. K. (1997). Inclusão. Construindo uma sociedade para todos. Rio de Janeiro: WVA.

Stobäus, C. D. (2001a). Testimonio de profesores de alumnos con necesidades educativas especiales. El desafío de la Educación Inclusiva. Proceedings of the IVth Encuentro Mundial de Educación Especial: Congreso Internacional de Psicomotricidad Infantil, Santo Domingo, 8-11 Noviembre 2001, 78-96.

Stobäus, C. D. (2001b). Entrevista con Ángel Riviére sobre Educación Especial. Educação-PUCRS, 24, 7-31.

Stobäus, C. D. (2001c). Professor Reports on Students Requiring Special Education: Elements for a Curricu1lar Reform. Journal of the International Society for Teachers Education, 5, 48-55.

Stobäus, C. D., \& Mosquera, J. J. M. (2001). O Mal-estar na Docência. In II Simpósio Internacional de Educação Superior (pp. 52-53). São Leopoldo: UNISINOS.

Stobäus, C. D., \& Teixeira, T. C. (2001a). Educação Inclusiva: Testemunho de professores de ANEE. In 53ª Reunião Anual da SBPC (on CD-Rom). Salvador: Sociedade Brasileira para o Progresso da Ciência-SBPC

Stobäus, C. D., \& Teixeira, T. C. (2001b). Educação Inclusiva: Testemunho de professores de ANEE. In II Salão de Iniciação Científica da PUCRS (on CD-Rom). Porto Alegre: PUCRS..

Stobäus, C. D., \& Mosquera, J. J. M. (org.). (2013). Educação Especial: Em direção à Educação Inclusiva (4th ed.). Porto Alegre: EDIPUCRS. 
T. C. Teixeira et al.

UNESCO (1994a). Necesidades Especiales en aula: Conjunto de materiales para la formación docente. Salamanca: UNESCO.

UNESCO (1994b). Declaração de Salamanca e linha de ação sobre necessidades educativas especiais. Brasília: CORPE. 